\title{
Civil Judge In Tanzania: Remuneration System And Promotion Possibilities - How To Reward Efficient And Independent Decisions
}

\author{
Elizabeth Swai and Magdalena Sylister*
}

\section{A. INTRODUCTION}

This paper examines systems for remuneration and promotion of civil judges in Tanzania and it further discusses means for rewarding efficient and independent decision. In doing so, the paper starts with a very brief explanation of the concept of a civil judge in Tanzania then it proceeds to talk about the yardstick of an efficient and independent decision. After that, the paper looks at the significance of efficient and independent decisions. That part is followed by the system of remuneration and promotion of judges in Tanzania and lastly, the paper talks about how efficient and independent decisions can be rewarded.

\section{B. THE CONCEPT OF A CIVIL JUDGE IN TANZANIA}

In Tanzania, a judge is a judicial officer who sits in higher courts only namely the High Court and the Court of Appeal. Judicial officers who sit in lower courts (primary courts, district courts and resident magistrate's courts) are referred to as Magistrates. There are also other specialized parallel judicial organs such as tribunals and commissions which are inferior to the High Court. Adjudicators in those bodies have special titles such as chairpersons, arbitrators, mediators et cetera. In addition to that, in Tanzania there is no distinction between civil judges and criminal judges. Generally, the same judges who preside over civil cases also preside over criminal cases except for judges of the Commercial Division of the High Court who in most cases adjudicate commercial disputes only filed before that Division.

In the past we used to have a Division of the High Court for land cases only and another Division of the High Court for employment and labour cases. The intention to create those divisions was very good but in reality, that idea failed because the divisions were overpowered with backlogs of cases. As a result, respective jurisdictions of those two divisions were conferred to the High Court main registry and those divisions were abolished except

* Elizabeth Swai, Tanzanian, Senior State Attorney, Senior Legal Officer at the Tropical Pesticides Research Institute, Arusha, LL. B. (Hons), University of Dar es salaam; lizmonsimon@gmail.com.

Magdalena Sylister, Tanzanian, Assistant Lecturer at the Saint Augustine University of Tanzania, Arusha, Tanzania; LL. M. (Distinction), University of Dar es salaam, Tanzania in association with the University of Bayreuth, Germany; LL. B. (Hons), University of Dar es salaam; Executive Director of the Foundation for Research and Assistance in Law; Advocate of the High Court and courts subordinate thereto save for primary courts, magdalenasylister@gmail.com. 
for Dar essalaam only. It is also worth mentioning that those divisions which still exist in Dar essalaam do not have exclusive jurisdictions.

\section{YARDSTICK OF AN INDEPENDENT AND EFFICIENT DECISION}

Considering that this paper is partly about promotion of judges in relation to rewarding independent and efficient decisions, there is a need to first look at what an independent and effective decision is expected to look like. Such decision should have at least the following features:-

First, it should show that the Judge has not been influenced by personal will or interest in the outcome of the case or that he/she has not been influenced by malice or by ill will, nepotism or any negative issue of any kind other than that the decision has been based on predetermined normative standards embedded in the law. ${ }^{1}$ There should be no improper influences, inducements or pressures, direct or indirect from any quarter or for any reason. ${ }^{2}$

The independence of the judge making that decision must be free from relatives and friends, independence from the litigating parties and the public, independence from fellow Judges and Judges responsible for managing the system (including the President or Chief Judge of the Court), independence from office holders in other branches of the government. ${ }^{3}$ The Judge's master is the law and so from the moment he/she is appointed as Judge, he/she must act without any dependence on another. ${ }^{4}$

According to Global Integrity findings, Tanzania has laws guaranteeing the independence of the judiciary. ${ }^{5}$ Even in practice, judges overall have the autonomy to interpret and review existing laws and are appointed through a merit-based system. ${ }^{6}$ The judiciary has proven its autonomy with the prosecution of two former cabinet members for abuse of office in 2015 and upholding the ruling despite subsequent appeals ${ }^{7}$

Second, the decision should be a product of procedural fairness and it should guarantee protection of human rights. ${ }^{8}$

According to the Legal and Human Rights Centre, ${ }^{9}$ a good example of courts playing a role in protecting human rights in 2016 is the decision by the High Court of Tanzania in the

1 Commonwealth, Magistrates and Judges' Association, Judicial Independence: The Challenges of the Modern Era, Conference Report, 2014, p. 11, https://cmja.org/downloads/confreports/Conferenc e\%20Report\%20Zambia.pdf (last accessed on 12/10/2018).

2 Note 1.

3 Note 1, p. 12.

4 Note 1, p.12.

5 Global Integrity, African Integrity Indicators - Country Findings, 2016, p. 2, http://www.globalinteg rity.org/wp-content/uploads/2016/05/AII4-Findings-Tanzania.pdf (last accessed on 13/10/2018).

6 Note 5.

7 Https://www.business-anti-corruption.com/country-profiles/tanzania/..

8 Commonwealth, Magistrates and Judges' Association, note 1.

9 A nongovernmental human rights organisation.. 
case of Rebeca Gyumi ${ }^{10}$, declaring the age of marriage for boys and girls to be 18 years and provisions allowing child marriage within the Law of Marriage Act unconstitutional. ${ }^{11}$ The provisions which were declared unconstitutional are those which allow girls to marry at the age of 14 and 15. The High Court then directed the Government to amend the marriage law within one year starting from the date of the judgment, making 18 years the age where citizens (male and female) can enter into marriage. ${ }^{12}$ Instead of carrying out the amendments as directed, the Government appealed against the decision and the appeal is still pending. We hope that the Court of Appeal will confirm the bold and wise decision of the High Court. Rebeca Gyumi, a Tanzanian, is one of the recent winners of the United Nations Human Rights Prize for 2018.

Third, the decision must be free from arbitrariness ${ }^{13}$ because judicial decisions must be based on facts and law. ${ }^{14}$

Fourth, the decision must be free from corruption. ${ }^{15}$

The Judiciary in Tanzania was named as the third most corrupt institution, after the Tanzania Police Force and the Tanzania Revenue Authority (TRA), according to the 2015 Transparency International Global Corruption Barometer. ${ }^{16}$

Fifth, the decision must be free from technicalities and instead, it must embrace substantial justice.

The Court of Appeal of Tanzania has sadly andextremely been notorious for entertaining legaltechnicalities to the extent that a huge percentage of appeals before it per session are struck out on technicalities. One Tanzanian prominent lawyer commented that our justice system has effectively been reduced to a race, in which the first person to spot the error wins irrespective of the merits of his case. ${ }^{17}$

In Civil Appeal No. 62/2001 Sunny Engineering and Auto Works Limited versus Ally Yusufu Mpore, the appellant's record of appeal before the Court of Appeal did not contain a copy of the pleadings from the trial court. ${ }^{18}$ The Appellant applied for amendment but the prayer was rejected on the ground that there was nothing before the Court to be amended. ${ }^{19}$

Recently, the Court of Appeal made two rulings in which it struck out two appeals, drafted for some prison inmates, for the incurable sin of misspelling the names of the

10 Rebeca Z. Gyumi v. Attorney General, Civil Cause number 5 of 2016, High Court of Tanzania (Unreported).

11 Legal and Human Rights Centre (LHRC), Tanzania Human Rights Report, 2016, p. 156.

12 Note 11.

13 Commonwealth, Magistrates and Judges' Association, note 1, p. 12.

14 Note 13, p. 13.

$15 \mathrm{Https} / /$ www.export.gov/article?id=Tanzania-Dispute-Settlement..

16 Note 15.

17 Beatus Malima, Litigation: The Court of Appeal Rules, 2009 and the Administration of Justice in Tanzania, 2012, p. 8.

18 Note 17, p. 9.

19 Note 17. 
judges who convicted them in their notices of appeal. ${ }^{20}$ In the first appeal the trial judge was referred to as "Twaribu", instead of Twaib and in the other appeal, the trial judge was referred to as "Bogore" instead of Bongole. ${ }^{21}$ These notices were drafted for the prisoners by the prison wardens. ${ }^{22}$

The sixth feature of an independent and efficient decision is that decisions must be delivered on time because when justice is delayed it is as good as it has been denied.

In recent years we have witnessed very positive efforts by the government and the judiciary aimed at solving the problem of delay of justice. Those efforts include establishing and implementing strategic case management systems, strictness in discouraging and disallowing unjustified adjournment of cases from parties etc.

Also, with effect from this year jurisdiction to determine employment and labour disputes at the High Court level have been conferred to the High Court main registry so as to speed up disposal of those disputes. Previously, exclusive jurisdiction in those disputes was vested in the special division of the High Court known as the Labour Court, however, that system led to a tremendous delay of justice especially in registries located outside Dar es salaam due to shortage of manpower and resources. The reforms have started taking effect a few months ago and so we hope that they will be very fruitful.

\section{SIGNIFICANCE OF EFFICIENT AND INDEPENDENT DECISIONS}

An efficient and independent decision has the following significance;

It guarantees trust, satisfaction and transparency.Decisions are made so as to determine a certain matter in question, the matter to be determined involves parties who are directly going to be affected by the decision. A decision which is made efficiently and independently directly guarantees that the parties will be in a position to trust the decision, the decision maker and the parties subjected to the decision will be satisfied by the position in the said decision. ${ }^{23}$ That decision will be obtained in the right way, which means parties to it either directly or indirectly will be in a position to know and to understand the basis of that decision.

It guarantees respect and rule of law. Efficient decisions are decisions which have been made by considering all the legal requirements to be observed in making decisions. Such a decision will be a result of the guidance, limits and requirement of the law. ${ }^{24}$ Since the decisionmaker will ensure that legal requirements have been observed, that is a guarantee that there is respect to the law and there is observation of the principles of rule of law.

20 M. J., Lugaziya, Application of Legal Technicalities and its Consequences on the Administration of Justice in Tanzania, pp. 1-2.

21 Note 20, p. 2.

22 Note 20, p. 2.

23 P.H \& J. Blenkinsopp, The Roles of Transparency and Trust in Relationship Between Corruption and Citizen Satisfaction, p. 5.

24 Www.venice.coe.int. 
It promoters professionalism.Decision making organs are composed with people who have some qualifications as the requirements may be. These people are well equipped with knowledge and skill on how to determine matters which arise for them to determine. The ability of these people to determine the matter in question in accordance with the requirement and without any influence or motivation promotes the skills and knowledge that a decision maker has. ${ }^{25}$ Being in a position in which you can decide and determine the matter in question freely promotes confidence, motivates creativity and promotes professional performance of the decision maker.

It is the determinant of the effectiveness of the decision making organ. How effective the decision making organ is, will be determined by the looking on how efficient and independent the decision of that organ will be. Where there are no indications that a decision was made out of any influence, directly that will show that the decision making organ is effective and reliable. ${ }^{26}$ But where the decision seems to be obtained in a manner that raises reasonable questions as to how it was obtained and where there are clear indications that there were unacceptable influences, those will be direct signs that the organ is not effective and reliable.

It promotes Justice.The main focus for determining a dispute is to justify the rights of either parties. Furthermore, decisions are made by considering the evidence available, laws, rules, regulations or customs applicable depending of the matter and the organ responsible for determination. Having an efficient and independent decision promotes justice in the sense that disputes will be determined in the right way and decisions will be made according to the available laws, rules or customs and consideration of sufficient and available evidence and not unacceptable influences. ${ }^{27}$

\section{E. JUDGES' REMUNERATION SYSTEM IN TANZANIA}

Remuneration of judges in Tanzania is governed by the Judges (Remuneration and Terminate Benefits) Act, 2007.The said remuneration comes in different forms as discussed below;

Salaries and allowances. These items are determined by the President and are charged on the consolidated fund. In addition to that, judges are exempted from payment of income tax.

Other benefits. Apart from salaries and allowances, judges receive other benefits as provided for under Schedule 1 of the Act, but those benefits may be subject to modifications as the President thinks fit provided that the modifications shall not curtail or reduce what is provided under the schedule. The first one is residence which comprises of a rent free fully furnished grade A residence, one house attendant, basic house held appliances, an allo-

Www.deloitte.com.

26 Www.omicsonline.org.

27 Www.justice.gov.za. 
wance of a sufficient amount to pay for water, waste disposal, electricity bills and local telephone calls.

Secondly, a judge is entitled to a travelling allowance while travelling on duty or on leave. If a judge wishes to travel by air, he/she is entitled to a business class ticket. If he/she travels by water, he/she is entitled to a first class ticket. If the judge wishes to use road transport, he/she is entitled to a chauffer-driven government vehicle. In case a judge is travelling for leave, his/spouse and children will be included in the aforesaid packages.

In addition to the aforesaid, judges are entitle to special allowances for purchasing court attire once annually, medical care for themselves together with their spouses and children, a personal assistant, fuel allowance at the rate of 70 litres per week, protection by a police guard at home and when travelling by surface or water while in office. A judge is also entitled to a salary while on an annual leave, an insurance cover against personal injury and accident out of and in the course of duty and a diplomatic passport which includes the judge's spouse. Upon demise, a judge is entitled to funeral expenses in terms of a coffin, shroud, wreath, costs of the grave, transport as well as cash to assist preparation and organization of funeral and burial ceremony.

Upon retirement, a judge is entitled to attractive retirement benefits in accordance with the provisions of Sections 20 and 21 of the Public service Retirement Benefits Act. Parallel to that, in case a judge has been removed from office in terms of Article 110 of the Constitution of United Republic of Tanzania, all the benefits earned by a judge before a attaining the age of retirement shall paid to him as the President thinks fit.

\section{F. PROMOTION OF A JUDGE}

In principle, promotion of judges should be based on objective factors, in particular merit, having regard to qualifications, integrity, ability, efficiency ${ }^{28}$ and experience. ${ }^{29}$ Political considerations should be inadmissible also other improper factors not linked to the professional merits of the judges concerned are thus not to be considered for purposes of promotion. ${ }^{30}$ Such improper factors might, for instance, include attitudes of discrimination based on gender, race or ethnicity. ${ }^{31}$

Transparent and rule - based appointment and promotion procedures can support the creation of a professional, highly competent judiciary. ${ }^{32}$ Alternatively, appointment and

28 Consultative Council of European Judges, Opinion no 1 (2001) of the Consultative Council of European Judges (CCJE), https://rm.coe.int/1680747830 (last accessed on 25/10/2018).

29 Independence and impartiality of Judges, Prosecutors and Lawyers, Human Rights in Administration of Justice : A Manual on Human Rights for Judges, Prosecutors and Lawyers, p. 129, https://w ww.ohchr.org/Documents/Publications/training9chapter4en.pdf (last accessed on 25/10/208).

30 Note 29.

31 Note 29.

32 Judicial Reform for Improving Governance in Anglophone Africa: TANZANIA NATIONAL ACTION PLANS DEVELOPED BY THE COUNTRY PARTICIPANTS, p. 2, http://www.tanzaniaga 
promotion systems that are dominated by political consideration and excessive discretion can serve to discredit the judiciary, discourage the recruitment of high - quality staff, and encourage poor performance." 33

Progressive judges should be promoted and be given other incentives. ${ }^{34}$ A candidate's track record of independent judging, or previous litigation or activism in political or constitutional matters, will also be a matter for some attention. ${ }^{35}$

In Tanzania, there is no machinery which provides for the promotion of judges, ${ }^{36}$ meaning that it is very difficult to ascertain whether or not a promotion of a judge has complied with the requisite standards. Parallel to that, the executive has a greater control on selection, which includes promotion, of judges, without having another organ to countercheck this selection. ${ }^{37}$ This could undermine the performance of the court in adhering to human rights in the country. ${ }^{38} \mathrm{Also}$, that process is criticized for its non-transparent nature. ${ }^{39}$

While there are advisory committees that play a role at entry level into the judiciary, higher level appointments are made almost exclusively by the Executive, and most promotions and appellate appointments follow that route. ${ }^{40}$ This is characterised by ad hoc procedures for consultations. ${ }^{41}$

Despite those shortcomings, there are some promotions which appear to have been based on the proper considerations. A good example is the promotion of the Current Chief Justice, Honourable Professor Ibrahim Juma, from a judge of the High Court to a judge of the Court of Appeal and now the Chief Justice. He is surely capable, his level of integrity is very high and he has greatly facilitated reforms in the justice system by introducing the overriding principle which emphasizes commitment to substantial justice instead of legal technicalities in administration of justice. Also he has reformed the employment and labour court system by conferring jurisdiction to the High Court to adjudicate labour disputes so as to expedite disposal of those disputes.

teway.org/docs/Judicial_Reform_for_Good_Governance_tanzania.pdf (last accessed on 25/10/2018).

33 Note 32.

34 Note 32, p. 3.

35 Hugh Corder\& Jan Van ZylSmit (Eds.), Securing Judicial Independence: The Role Commissions in Selecting Judge in the Commonwealth (2017), p. ix, https://www.biicl.org/documents/1834_corder _and_smit_-_securing_judicial_independence.pdf?showdocument $=1$ (last accessed on 26/10/2018).

36 Judicial Reform for Improving Governance in Anglophone Africa, note 32, p. 3.

37 Legal and Human Rights Centre (LHRC), Tanzania Human Rights Report, 2015, p. 209.

38 Legal and Human Rights Centre (LHRC), note 37, p. 209.

39 Https://www.export.gov/article?id=Tanzania-Dispute-Settlement..

40 Hugh Corder\& Jan Van ZylSmit, note 35, p. xii.

41 Note 40. 
It has been recommended that clear guidelines for the promotion of judges should be established. ${ }^{42}$ Also, other sources have repeatedly recommended the use of bodies that are independent from the executive, plural and composed mainly of judges and members of the legal profession, and that apply transparent procedures. ${ }^{43}$

The general observation of this paper is that if promotions are not done in accordance with the required standards, it will be difficult to rip independent and efficient decisions especially in critical disputes which are surrounded with heavy clouds of pressure and undue influence from the executive, the haves, relatives, personal convictions et cetera.

As a result, this paper agrees with the recommendations discussed above that there should be proper guidelines and adequate transparency in the process of promoting judges. Not only that but also, promotion of judges should be done by bodies that are independent from the executive.

\section{G. HOW TO REWARD EFFICIENT AND INDEPENDENT DECISIONS}

Judges delivering efficient and independent decisions should be rewarded in the following ways:-

They should be given priorities in promotions. The obvious outcome is that senior positions will be covered with competent and efficient judges who will keep advancing the justice delivery system.

Promotions should be to areas which match their expertise and not to areas which they are not well conversant with. For example, a judge who is good in deciding commercial disputes should remain in that area so that he/she can continue advancing the commercial jurisprudence.

Promotions should be free from the control of the executive and instead, they should be carried out by an independent body.

Competent judges should continue to be well remunerated so as to motivate them, encourage them and suppress any appetite for bribery.

Competent judges should be highly respected and budgets of the judiciary should be under the full control of the judiciary.

Moreover, competent judges should be given maximum security because some decisions which they make expose them to serious threats especially of their lives. A good example of such threats is in the famous ERASTO MSUYA'S CASE. ${ }^{44}$ ERASTO MSUYA was a billionaire and a Tanzanite Gemstone dealer with high-end properties both in Moshi and Arusha regions in Tanzania. He was shot several times around noon on $7^{\text {th }}$ August,

42 Judicial Reform for Improving Governance in Anglophone Africa, note 32, p. 3.

43 Jill Cottrell Ghai (Ed.), Judicial Accountability in the New Constitutional Order, p. 19, https://icj-k enya.org/jdownloads/Publications/ICJ_Judiciary_Watch_ed_12_final_complete_for_web.pdf (last accessed on 13/10/2018).

44 Republicv Sharifu S/O Mohamed @ Athumani and Others, Criminal Session Case No. 12 of 2014, High Court of the United Republic of Tanzania (Unreported). 
2013, in a bush close to the Kilimanjaro International Airport along the Moshi-Arusha highway.

There were seven accused persons who were arraigned before High Court of Moshi in connection to the shooting. After trial, judgment was delivered on $23^{\text {rd }}$ July, 2018 whereby one of the accused persons was acquitted since the evidence adduced by the prosecution failed to link him directly to the murder. The other accused persons were convicted and sentenced to suffer death by hanging.

Surprisingly, on $30^{\text {th }}$ July, 2018 one Norbert Anthony Lyimo called a court official purposely to insult and threaten the judge for the outcome of the decision as he was not happy beacuse one of his relative was sentenced to death. The said Norbert even intimidated the court officials that he will burn the High Court - Arusha buildings. The possible reason as to why those threats were directed to High Court Arusha buildings instead of Moshi Kilimanjaro is because Arusha was the permanent work station of the judge who presided over the case. A few months later the judge was transferred to another station. Somehow the transfer has provided security to the judge since she will be far away from the convicts' relatives.

Also, Mr. Norbert has now been arraigned before the Resident Magistrate Court of Arusha with two counts namely using abusive language and threatening with violence.

\section{H. CONCLUSION}

Efficient and independent decisions are the cornerstone of justice delivery and respect for rule of law in Tanzania. Judges who deliver such decisions should be adequately promoted, well remunerated and effectively protected so as to motivate them to keep delivering efficient and independent decisions. 